\title{
Use of blubber fatty acid profiles to distinguish dietary differences between grey seals Halichoerus grypus from two UK breeding colonies
}

\author{
M. J. Walton ${ }^{1, *}$, R. J. Henderson ${ }^{2}$, P. P. Pomeroy ${ }^{1}$ \\ ${ }^{1}$ Sea Mammal Research Unit, University of St Andrews, St Andrews KY16 8LB, Scotland, UK \\ ${ }^{2}$ Institute of Aquaculture, University of Stirling, Stirling FK9 4LA, Scotland, UK
}

\begin{abstract}
The population structure of grey seals Halichoerus grypus has previously been studied using molecular biological techniques. These works may be complemented by studies of certain ecological factors which play an important role in providing information on habitat usage, dietary behaviour, local migrations, distribution and social structure. One such factor is the fatty acid composition of depot fats, which is strongly influenced by the fatty acid composition found in the prey. To examine the extent to which the fatty acid composition of seal depot fats can be used to distinguish between populations, blubber biopsy samples were obtained from female grey seals at 2 Scottish breeding sites, Rona $(n=23)$ and the Isle of May $(n=34)$ and the fatty acid compositions determined by gas chromatography. The patterns obtained were compared using both univariate and multivariate statistical procedures. Fatty acid profiles at the 2 breeding sites could be clearly differentiated, with only 1 . seal out of 57 being mis-classified. Thus, on the basis of blubber fatty acid composition, they may be regarded as 2 distinct foraging groups.
\end{abstract}

KEY WORDS: Fatty acids - Grey seals - Population discrimination

\section{INTRODUCTION}

Approximately 110000 (one-third of the total world population) grey seals Halichoerus grypus inhabit the coastal waters of Britain (especially Scotland). Once a year, for a few weeks, seals gather at certain onshore sites for breeding. Seals at 2 Scottish breeding sites, namely Rona $\left(59^{\circ} 06^{\prime} \mathrm{N}, 05^{\circ} 50^{\prime} \mathrm{W}\right)$ and the Isle of May $\left(56^{\circ} 10^{\prime} \mathrm{N}, 2^{\circ} 33^{\prime} \mathrm{W}\right.$ ) (Fig. 1) have been studied extensively for more than 10 yr (Anderson \& Fedak 1987 , Pomeroy et al. 1999). Allen et al. (1995) tested the degree of breeding-site fidelity by screening over 1000 seals with 8 microsatellite loci. They found a mean inter-population distance $F_{\mathrm{st}}$ of 0.006 , which is a low value and indicative of a high level of gene flow. Nevertheless there is a highly significant difference $(p<$ 0.001 ) between the 2 colonies, so they can be regarded as separate genetic populations (interbreeding units).

•E-mail:mjw6@st-andrews.ac.uk
Female seals do not eat while onshore to give birth and suckle their young. They rely on their energy reserves (especially lipid) for maintenance and for milk production (Anderson 1990). Thus, in the months before breeding, females must eat sufficient amounts of food to fully replenish their energy reserves, which are an important factor in successful reproduction (Pomeroy et al. 1999). However, much remains unknown about the movements and foraging behaviour of most seals during these months. Satellite telemetry has provided useful information on the movements of a few grey seals (mainly males), but its widespread application is restricted by its high cost. The technique has been applied to seals from east Scotland (but not Rona) and has shown that some seals tend to travel only relatively short distances to and from favoured foraging sites while others can and do travel many hundreds of kilometres in a few days (McConnell et al. 1992, 1999). If long distance travel is extensive then seals from different breeding populations may intermingle at the same foraging areas and hence could be 


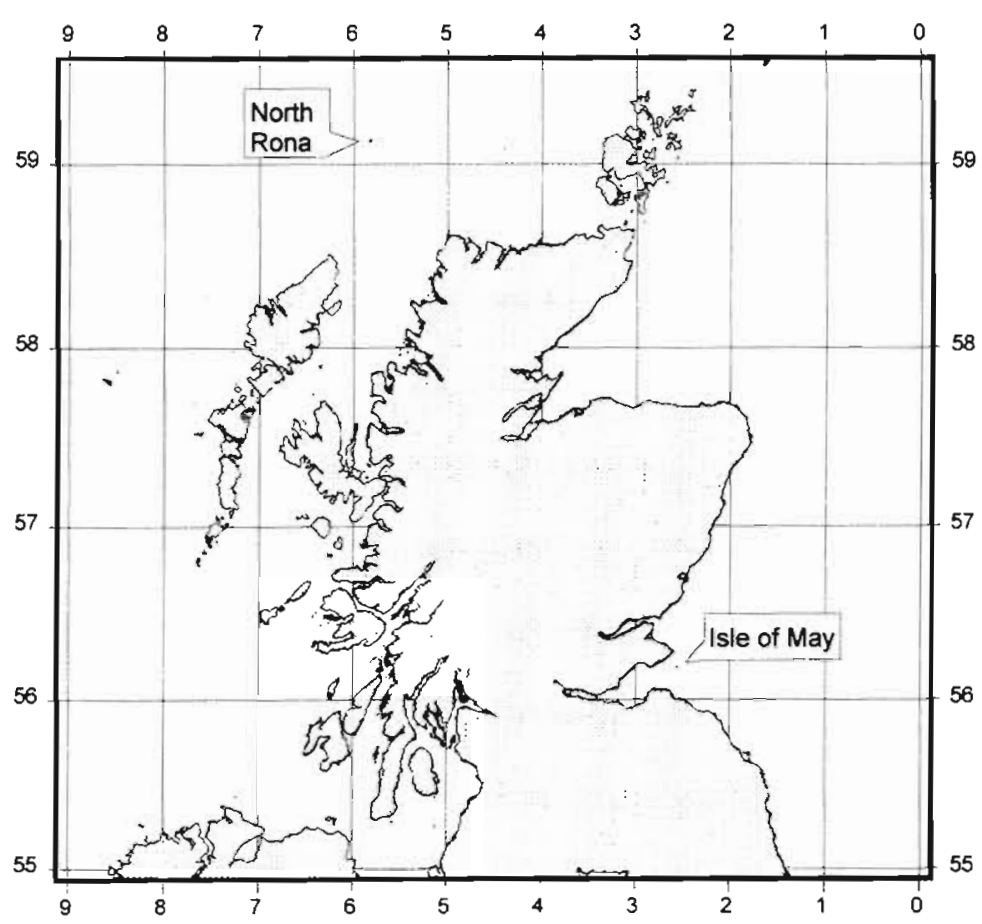

Fig. 1 Locations (latitude and longitude) of the 2 breeding colonies on on Rona and the Isle of May

regarded as the same ecological 'population' (i.e. individuals occupying the same location with similar foraging behaviour). One way to investigate this is to study environmentally acquired characters which can provide information on habitat use, local migrations, foraging activities, distribution and social structure, but not breeding behaviour (Avise 1994). Blubber fatty acids are probably the most suitable such characters for studies on live animals since only small biopsy samples are required.

Ackman et al. (1970) postulated that many distinctive features of the fatty acid composition of marine organisms are passed through the food web and could be used to follow feeding patterns or identify populations. Marine oils typically contain a wide variety of fatty acids, many of which have their ultimate origin in phytoplankton (Sargent et al. 1995), although blubber fatty acid profiles are strongly influenced by the diet but are not identical to it, since some endogenously synthesised fatty acids as well as modified dietary fatty acids are also deposited (Iverson 1993). The technique has been used to distinguish between populations and/or dietary differences of several seal species (Ackman et al. 1971. West et al. 1979a, Grahl-Nielsen et al. 1993, Kakela et al. 1993, Smith et al. 1996, Iverson et al. 1997b), lobsters (Castell et al. 1995), fish (Iverson et al. 1997b) and foxes (Pond et al. 1995).

In the present study the fatty acid profiles of seals from Rona and the Isle of May were compared in order to investigate possible differences in diet and to complement the genetic work on population differentiation. If the seals from the 2 sites forage in different locations on different assemblages of prey then a difference would be expected in the profiles and they could be regarded as separate ecological 'populations'. Alternatively if there were extensive mixing at feeding grounds, then there would be little difference in profiles and no justification for differentiation.

\section{MATERIALS AND METHODS}

Tissue collection. In the course of related fieldwork (see Pomeroy et al. 1999 for details) female seals were captured and immobilised and blubber samples of about $0.5 \mathrm{~g}$ were collected using a $6 \mathrm{~mm}$ diameter disposable, single-use biopsy needle (Acuderm, Florida, USA). As fatty acid profiles can vary with the site on the body from which the sample is collected (Kakela \& Hyvarinen 1996) all samples were collected from the mid-pelvic region. There are reports of some stratification of blubber in grey seals (Fredheim et al. 1995) with increasing levels of saturated fatty acids and longer chain mono-unsaturated fatty acids (mainly 20:1 and 22:1) and decreasing levels of short chain mono-unsaturated fatty acids (mainly 14:1 and 16:1) from outer to inner but little change in poly-unsaturated fatty acid levels. All biopsy samples comprised a complete crosssection of blubber from skin to muscle and were taken around the start of the lactation period. All procedures were performed under the appropriate UK Home Office licences.

As Rona and the Isle of May are remote locations, it was not possible to freeze the samples immediately after collection. Samples (about $500 \mathrm{mg}$ ) were stored in chloroform:methanol (2:1, vol/vol) containing $0.05 \%$ butylated hydroxytoluene (BHT) as antioxidant until being returned to the mainland some 2 to 3 wk later, where it was possible to store them at $-20^{\circ} \mathrm{C}$ until analysis a few months later (Iverson et al. 1997b).

Samples were taken from 23 breeding females at Rona during the period 4 to 24 October 1996, and 34 breeding females at the Isle of May from 2 to 22 November 1996

Lipid extraction. Total lipid (essentially triacylglycerol) was extracted from the blubber using the method of Folch et al. (1957). Thus, biopsy samples were homogenised in $25 \mathrm{ml}$ chloroform:methanol (2:1, vol/ vol) containing $0.01 \% \mathrm{BHT}$ as antioxidant and filtered. The organic phase was washed with $0.9 \% \mathrm{KCl}$ and 
dried over anhydrous sodium sulphate. An aliquot was taken to dryness and weighed.

Fatty acid methylation/purification. Fatty acid methyl esters were prepared and purified as described by Henderson et al. (1994) using 1\% (vol/vol) sulphuric acid in methanol as the methylating reagent and incubation for $16 \mathrm{~h}$ at $50^{\circ} \mathrm{C}$ under nitrogen. The purified methyl esters were dissolved in hexane $\left(1 \mathrm{mg} \mathrm{ml}^{-1}\right)$.

GC analysis. Fatty acid methyl esters (FAME) were analysed by gas-liquid chromatography (glc) using a Canberra Packard 436 gas chromatograph equipped with a flame-ionization detector and fitted with a BP20 fused silica capillary column $(30 \mathrm{~m} \times 0.32 \mathrm{~mm}$ internal diameter, S.G.E. Ltd, Milton Keynes, UK). Hydrogen was employed as the carrier gas and sample application was by on-column injection. The temperature of the oven was programmed to rise from 50 to $150^{\circ} \mathrm{C}$ at $35^{\circ} \mathrm{C} \mathrm{min}{ }^{-1}$ and then to $225^{\circ} \mathrm{C}$ at $2.5^{\circ} \mathrm{C} \mathrm{min}^{-1}$ during each analysis. Separated components were identified by reference to authentic standards and a well-characterised fish oil and were quantified by means of a Shimadzu CR6A integrator attached to the gas chromatograph. Individual fatty acids are expressed as mass percent of the total fatty acids characterised.

Statistical treatment of results. Procedures contained within the computer Statistics package SYSTAT (version 7.0 for Windows, SPSS Inc., Chicago) were used to classify or test for differences between the fatty acid profiles from the 2 locations. Three multivariate approaches were applied: principal component analysis, discriminant analysis and classification TREE analysis. The purpose of principal component analysis is to reduce the large number of original correlated variables to a small number of transformed uncorrelated variables. It derives a small number of linear combinations (principal components) that retain as much of the information in the original variables (in this case fatty acid percentages) and also explain as much of the sample variance as possible. It is essentially a way of uncovering linear dependencies among a set of variables. Discriminant analysis shows to what degree it is possible to separate 2 or more groups of individuals given measurements of several variables. It provides linear functions of the variables that best separate the cases into 2 or more predefined groups. The use of CART (classification and regression trees), a non-parametric multivariate technique for classifying data, to study fatty acid profiles was fírst advocated by Smith et al. (1997). Classification trees are used when the dependent variable (in this case geographic location) is categorical rather than continuous, and they were computed using the TREES module of SYSTAT. The module uses an algorithm to automatically select the optimal variable for splitting data into 2 groups that are as different as possible. Graphical trees are produced consisting of a number of nodes and branches. The top node contains the entire sample set. Each remaining node contains a subset of the sample of the node directly above it. The tree is binary because each node splits into 2 subsamples and the splits are determined by whether the levels of a fatty acid (selected by the analysis as the best for this purpose) are above or below some cut-off value. The impurity value is a measure of the levels of mis-classifications within the node.

\section{RESULTS}

The fatty acid compositions (\% total fatty acids) of the blubber of grey seals from Rona and the Isle of May are shown in Table 1. Overall the patterns were similar with the 5 most abundant fatty acids 18:1(n-9), 22:6 $(n-3), \quad 16: 1(n-7), \quad 16: 0$ and $20: 1(n-9)$ accounting for about $60 \%$ of the total. Polyunsaturated fatty acids accounted for one-third of the total. The samples were rich in (n-3) compared to (n-6) fatty acids, with the ratios of $(n-3) /(n-6)$ being 0.10 and 0.14 for Rona and the Isle of May, respectively. There was no single fatty acid present in all samples from one of the geographical areas but absent in all samples from the other area, which could be used as an identifier for seals from that area. There were no significant differences between the totals of saturated, mono-unsaturated, polyunsaturated, (n-3) or (n-6) fatty acids. The fatty acids showing the greatest change, on a percentage basis, were firstly $22: 4(n-6), 20: 4(n-6)$ and 16:4(n-1), which were respectively 79,48 and $39 \%$ higher in samples from Rona than from the Isle of May; and secondly 20:3(n-3), $18: 3(n-3), 18: 4(n-3), 18: 2(n-6)$ and $22: 1(n-9)$, which were respectively $59,52,44,43$ and $38 \%$ higher in samples from the Isle of May than from Rona.

In the relative \% contribution to the overall profile, there was a 270 -fold range between the minimum contributor (20:3n-3) and the maximum contributor $(18: 1 n-9)$. To prevent undue influence of the more abundant fatty acids in the principal component analysis, the data must first be normalised. When using a correlation matrix in SYSTAT this is automatically performed, so that for each fatty acid the mean is subtracted from each value and the result divided by the standard deviation (see Storr-Hansen \& Spliid 1993) so that each fatty acid has the average value 0 and a standard deviation of 1 . The first 3 principal components sorted by magnitude are given in Table 2 . The first component explained $34 \%$, and the second component $18 \%$ of the total variance. A plot of the first 2 principal components which helps to visualise any clustering of the data, is shown in Fig. 2a, with the samples labelled by geographic location. Although the 2 groupings are 
not totally separated the Isle of May seals tend to be situated to the left of centre of the plot whereas the Rona seals tend to occupy the right half of the plot, with a small amount of overlap in the centre. One Rona sample (R18) appears in the midst of the Isle of May samples. The separation is improved with less overlap if fewer variables are considered, for instance if only the 3 fatty acids with the highest component loadings in Table 2 are used in the analysis (Fig. 2b).

For all the multivariate approaches the geographic locations were used as the classification variables and the fatty acid levels as the explanatory variables.

Table 1 Fatty acid composition of blubber sampled in the breeding season (October-November 1996) from grey seal adult females at Rona ( $n=23$ ) and the Isle of May $(n=34)$. Values are the mean weight percent \pm standard deviation

\begin{tabular}{|c|c|c|}
\hline Fatty acid & Rona & Isle of May \\
\hline $14: 0$ & $3.74 \pm 0.56$ & $3.44 \pm 0.59$ \\
\hline $14: 1 \mathrm{~s}$ & $1.07 \pm 0.22$ & $0.81 \pm 0.23$ \\
\hline $15: 0$ & $0.33 \pm 0.07$ & $0.29 \pm 0.06$ \\
\hline $16: 0$ & $9.09 \pm 1.15$ & $8.64 \pm 1.15$ \\
\hline $16: 1(n-9)$ & $0.47 \pm 0.08$ & $0.48 \pm 0.07$ \\
\hline $16: 1(n-7)$ & $11.96 \pm 1.59$ & $10.00 \pm 1.79$ \\
\hline $16: 2(n-4)$ & $0.44 \pm 0.12$ & $0.33 \pm 0.07$ \\
\hline $17: 0$ & $0.54 \pm 0.09$ & $0.41 \pm 0.07$ \\
\hline $16: 3(n-4)$ & $0.41 \pm 0.09$ & $0.32 \pm 0.10$ \\
\hline $16: 4(n-1)$ & $0.46 \pm 0.17$ & $0.33 \pm 0.18$ \\
\hline $18: 0$ & $1.23 \pm 0.34$ & $1.15 \pm 0.17$ \\
\hline $18: 1(n-9)$ & $21.17 \pm 2.48$ & $21.60 \pm 3.37$ \\
\hline $18: 1(n-7)$ & $3.31 \pm 0.66$ & $2.97 \pm 0.59$ \\
\hline $18: 2(n-9)$ & $0.34 \pm 0.04$ & $0.36 \pm 0.05$ \\
\hline $18: 2(n-6)$ & $1.62 \pm 0.38$ & $2.87 \pm 0.39$ \\
\hline $18: 3(n-3)$ & $0.85 \pm 0.27$ & $1.78 \pm 0.24$ \\
\hline $1.8: 4(n-3)$ & $1.57 \pm 0.53$ & $2.80 \pm 0.62$ \\
\hline $20: 1(n-11)$ & $0.84 \pm 1.00$ & $0.76 \pm 0.99$ \\
\hline $20: 1(n-9)$ & $7.72 \pm 1.88$ & $9.97 \pm 1.98$ \\
\hline $20: 1(n-7)$ & $0.29 \pm 0.08$ & $0.40 \pm 0.19$ \\
\hline $20: 2(n-6)$ & $0.24 \pm 0.06$ & $0.37 \pm 0.11$ \\
\hline $20: 4(n-6)$ & $0.82 \pm 0.20$ & $0.56 \pm 0.14$ \\
\hline $20: 3(n-3)$ & $0.08 \pm 0.09$ & $0.19 \pm 0.08$ \\
\hline $20: 4(n-3)$ & $0.79 \pm 012$ & $1.09 \pm 0.16$ \\
\hline $20: 5(n-3)$ & $6.10 \pm 1.17$ & $5.60 \pm 0.99$ \\
\hline $22: 1(n-11)$ & $2.98 \pm 0.98$ & $3.50 \pm 1.47$ \\
\hline $22: 1(n-9)$ & $0.41 \pm 0.11$ & $0.66 \pm 0.20$ \\
\hline $22: 4(n-6)$ & $0.20 \pm 0.08$ & $0.11 \pm 0.1 .0$ \\
\hline $22: 5(n-6)$ & $0.25 \pm 0.05$ & $0.21 \pm 0.09$ \\
\hline $22: 4(n-3)$ & $0.16 \pm 0.07$ & $0.23=0.11$ \\
\hline $22: 5(n-3)$ & $4.83 \pm 0.53$ & $4.66 \pm 0.48$ \\
\hline $22: 6(n-3)$ & $14.28 \pm 1.22$ & $12.51 \pm 1.17$ \\
\hline Unidentified & $1.43 \pm 1.93$ & $0.24 \pm 0.31$ \\
\hline Total & 100 & 100.00 \\
\hline Total saturated & $14.93 \pm 1.60$ & $13.92 \pm 1.65$ \\
\hline Total MUFA & $50.55 \pm 2.83$ & $52.03 \pm 2.14$ \\
\hline Total PUFA & $33.09 \pm 2.34$ & $33.96 \pm 1.54$ \\
\hline Total $(n-3)$ & $28.66 \pm 2.23$ & $28.87 \pm 1.56$ \\
\hline Total $(n-6)$ & $3.12 \pm 0.30$ & $4.11: 0.27$ \\
\hline
\end{tabular}

Discriminant analysis also proved very capable of distinguishing the blubber samples from the 2 areas in a posterion classification (Wilks' lambda $=0.069$, $F=10.1, \mathrm{p}=0.000$, df $=32,24)$. The classification matrix (Table 3a) shows a clear separation into 2 distinct groupings with only 1 mis-classified sample (R18), i.e. $98 \%$ accuracy. These results may be an over-optimistic estimate of the success of the analysis because the classification rule was evaluated using the same cases used to compute it. One means of cross-validation which attempts to remedy this problem uses jackknifed classification, which classifies each sample without using that sample to calculate the group means. If the percentages of correct classifications are considerably lower in the jack-knifed table then there may be too many predictors in the model. As Table $3 \mathrm{~b}$ shows, the jack-knifed classification matrix results in

Table 2. First 3 principal component (PC) loadings sorted by magnitude

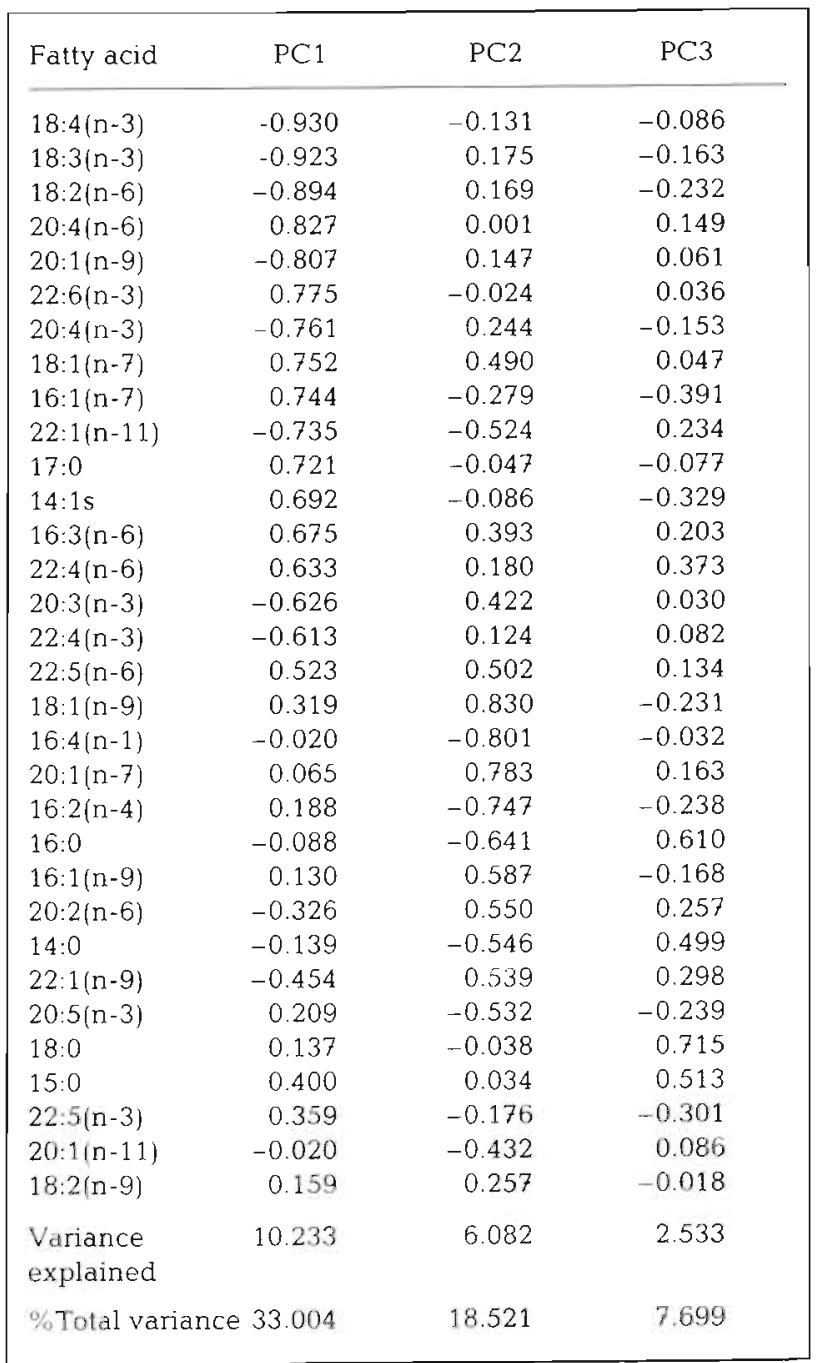


Fig. 2. (a) Plot of the first 2 principal components calculated from 32 fatty acids. The first and second components accounted for 33 and $18 \%$ of the total variance, respectively. (b) Plot of the first 2 principal components calculated from the 3 fatty acids showing the greatest component loadings. The first and second components accounted for 96 and $3 \%$ of the total variance, respec tively. Individual samples from the Isle of May ( $n=34)$ and Rona $(n=23)$ are indicated by the letters $M$ and $R$, respectively
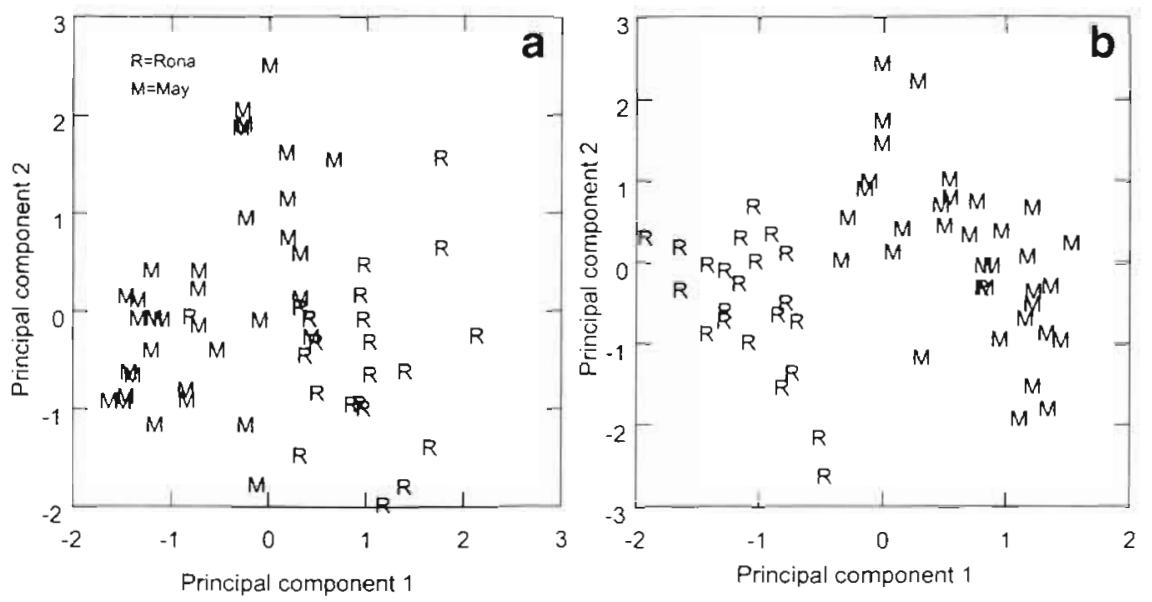

only a slightly lower (93 compared to $98 \%$ ) overall success rate. SYSTAT also has a stepwise modelling procedure for identifying the best subset of variables to use as predictors in this particular case. When this procedure was run the sub-set it chose in decreasing order of magnitude was 22:1(n-9), 20:1(n-7), $18: 2(n-6), 18: 1(n-7), 20: 2(n-6), 22: 5(n-3), 18: 3(n-3), 16: 0$ and $22: 1(n-11)$ and $18: 3(n-3)$. Using only these 9 fatty acids in the discriminant analysis gave classification matrices identical to Table $3 \mathbf{a}$, for both the 'standard' and jack-knifed tables. $(F=51.7, \mathrm{df}=9,47, \mathrm{p}<0.001)$.

The TREES classification analysis (Fig. 3) also distinguished the blubber samples from the 2 areas. The analysis classified samples with levels of $18: 2(n-6)>$ $2.13 \%$ as belonging to the Isle of May group whereas samples with levels of $18: 2(n-6)<2.13 \%$ belonged to the Rona group. On this basis only 1 seal (R18 from Rona) was mis-classified with the Isle of May samples. When the fatty acid 18:2(n-6) is omitted from the analysis, an identical tree was produced on the basis of the levels of $18: 3(n-3)$, where those with levels $>1.25 \%$ and $<1.25 \%$ occurring in the Isle of May and Rona

Table 3. (a) Classification matrix and (b) Jack-knifed classification matrix obtained from the discriminant analysis of the fatty acid profiles of seals from Rona $(n=23)$ and the Isle of May $(n=34)$

\begin{tabular}{|c|c|c|c|}
\hline & Isle of May & Rona & $\%$ correct \\
\hline \multicolumn{4}{|c|}{ (a) Classification matrix } \\
\hline Isle of May & 34 & 0 & 100 \\
\hline Rona & 1 & 22 & 96 \\
\hline Total & 35 & 22 & 98 \\
\hline \multicolumn{4}{|c|}{ (b) Jack-knifed classification matrix } \\
\hline Isle of May & 32 & 2 & 94 \\
\hline Rona & 2 & 21 & 91 \\
\hline Total & 34 & 23 & 93 \\
\hline
\end{tabular}

groups, respectively. Less clear classifications resulted if both of these fatty acids were omitted from the calculation.

\section{DISCUSSION}

The basis of this study for investigating fatty acid profiles is that in monogastric animals the composition of fatty acids in depot fat such as adipose tissue or blubber triacylglycerols is strongly influenced by that of the diet. However, even when the diet is controlled there is never complete correspondence of subject to prey profiles (Dayton et al. 1966). A direct connection between the fatty acid composition of dietary and storage lipids has been demonstrated in laboratory animals (Valero-Garrido et al. 1990), and samples of adi-

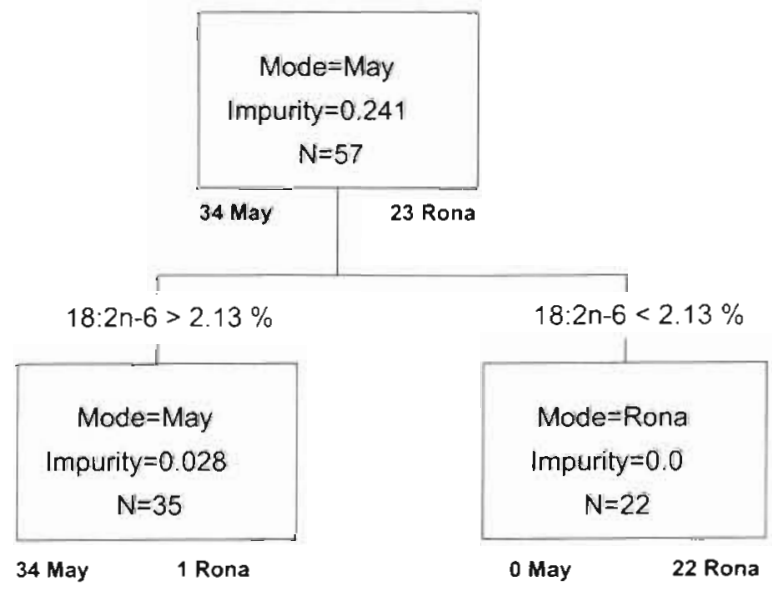

Fig. 3. Results of the classification tree analysis. The mode is the most abundant sample classification at each node. The impurity figure is based on probability distributions of mis-classified samples. N: number of samples at each node. Below each node-box are the numbers of samples from each of the 2 colonies 
pose tissue obtained by biopsy or other means have been shown to be a moderately accurate indicator of dietary habits in humans (Plakke et al. 1983, Field \& Clandinin 1984, Tjonneland et al. 1993). Studies of polar bears fed in captivity indicate that diet is important in determining adipose fatty acid composition in Carnivora (Colby et al. 1993). Feeding experiments with captive seals have shown that fatty acid profiles changed when the diet was switched from herring to mackerel (Grahl-Nielsen \& Mjaavatten 1991). In this latter study little similarity was found between the seal and fish fatty acid profiles, but the experimental procedure and conclusions have been criticised by Iverson (1993). Thus the alteration of fatty acid profile due to differences in diet has been used in the present study to investigate stock structure and foraging behaviour of seals from the 2 breeding colonies of Rona and the Isle of May.

The fatty acid profiles found in the seals from Rona and the Isle of May are typical of lipids found in the marine oils, being rich in unsaturated, polyunsaturated and (n-3) fatty acids. These major characteristics and overall pattern are basically similar to other reports for grey seal blubber (Ackman \& Hooper 1974, Ackman \& Eaton 1988, Schweigert et al. 1990, Grahl-Nielsen \& Mjaavatten 1991, Fredheim et al. 1995). The univariate procedure showed significant differences between a number of fatty acids, and the greatest percentage differences were seen mainly among the less abundant fatty acids. As pointed out by Grahl-Nielsen \& Mjaavatten $(1991,1995)$ comparisons are more clearly represented graphically using multivariate procedures. They used principal component analysis and discriminant analysis to demonstrate clear differences between harp seal pups and adults, as well as between populations of harp, hooded Cystophora cristata and harbour seals inhabiting similar locations in the Northern Atlantic and Barents Sea. The use of TREE classification methods in addition to these 2 procedures was introduced by Iverson and her co-workers (Iverson et al. 1997a,b, Smith et al. 1997). In a comparison of TREE and discriminant analysis on various data sets, Smith et al. (1997) found that both procedures were useful but neither procedure was consistently better than the other. Both principal component analysis and discriminant analysis have the disadvantage that more samples are needed than there are variables, so for small data sets TREE classification is useful either by itself or in pre-selecting the variables to use in the principal component analysis and discriminant analysis procedures.

In the present study all the analyses provided evidence that the 2 groups were different. The TREE classification and discriminant analysis (and principal component analysis using pre-selected variables) pro- duced identical results in separating out the samples into 2 groups with only 1 mis-classification. The same seal was mis-classified by all the statistical analyses. The female seals used in this study were all known to be site-faithful to either the Rona or the Isle of May breeding colonies, having been observed at the same site for several breeding seasons prior to the one during which they were sampled. These seals from the 2 breeding colonies also appear to have followed different feeding strategies before breeding, i.e. as well as being genetically separated they are also from different ecological populations. Fatty acid profiles are acquired characteristics so they are not transmitted across generations and do not delineate reproductive units; ecological stocks do not necessarily have any genetic significance.

Although a number of explanations exist for the differences in fatty acid profiles in seals from the 2 sites, the most likely is that the seals are foraging in separate areas and probably on a different mixture of prey species. It is not currently possible to identify the component prey species which contribute to the blubber fatty acid profiles in this study. Also, the actual diets throughout the year of the grey seals which were sampled at Rona and the Isle of May during the breeding season are unknown, but dietary analyses of faecal material from seals from the Orkney Islands, the Inner and Outer Hebrides and the Farne Islands have been performed (Hammond \& Prime 1990, Hammond et al. $1994 a, b)$. The results showed that grey seals feed on a wide variety of fish prey and that there are both seasonal and regional variations in the diet. About 30 different prey species were detected with 11 fish species making up over $90 \%$ of the diet. The major dietary items were sand eels for seals at the Orkney Islands, sand eels and gadoids for seals at the Farne Islands, whereas the main item for seals in the Hebrides were gadoids (cod, ling and whiting) with significant contributions coming from herring and mackerel. In east coast samples, sand eels were important prey in spring and summer but less so during the remainder of the year. Other explanations which are theoretically possible, but which may be considered unlikely in reality, are that the seals forage in the same areas but on different prey or that they are metabolically different in how they deposit and metabolise fatty acids in the blubber; or that the 2 groups have identical diets in 2 separate locations but that the fatty acid profiles of the prey species differ between the 2 sites. The 1 'misclassified' sample could be due to random variation in fatty acid composition amongst the Rona seals, or that it fed in a similar manner to seals from the Isle of May. However, it cannot be ruled out that this 1 seal may have foraged in the same feeding areas as the Isle of May, but returned to Rona for breeding. There was no 
apparent difference in the condition or behaviour of this seal compared to the other samples from Rona.

One important factor in the interpretation of fatty acid profiles is the turnover rate of fatty acids in blubber. We have no direct measures of the rate, but in continuously fed humans the half life of fatty acids in adipose tissue is slow, somewhere in the region of $2 \mathrm{yr}$ (Dayton et al. 1966). Iverson (1993) commented that blubber fatty acid probably reflected the dietary history over a few months. It is likely that turnover is low while the seal is actively feeding, but is high during the breeding season when up to $60 \%$ of the lipid reserves are mobilised for milk production and maintenance.

This study focussed on female seals from 2 sites but could also be applied to investigate other sites, seasonal and yearly variations in diet as well as possible differences in feeding behaviour between males and females. In many mammal groupings females tend to be philopatric while males tend to disperse (Greenwood 1980). Therefore it may be that males travel further than females and feed in different locations. Also, it may eventually be possible to relate certain fatty acid profiles to certain foraging locations if knowledge of movements of sampled seals can be obtained using satellite telemetry.

\section{LITERATURE CITED}

Ackman RG, Eaton CA (1988) n-3 docosapentaenoic acid in blubber of dam and pup grey seals: implications for the Inuit diet and for human health. Can J Zool 66:2428-2431

Ackman RG, Hooper SN (1974) Long chain monoethylenic and other fatty acids in heart liver and blubber lipids of 2 harbour seals and one grey seal. J Fish Res Board Can 31:333-341

Ackman RG, Eaton CA, Sipos JC, Hooper SN, Castell JD (1970) Lipids and fatty acids of 2 species of North Atlantic krill and their role in the aquatic food web. J Fish Res Board Can 27:513-533

Ackman RG, Epstein S, Eaton CA (1971) Differences in the fatty acid composition of blubber fats from northwestern Atlantic fin whales and harp seals. Comp Biochem Physiol 40B: $683-697$

Allen PJ, Amos W, Pomeroy PP, Twiss SD (1995) Microsatellite variation in grey seals shows evidence of genetic differentiation between 2 British breeding colonies. Mol Ecol $4: 653-667$

Anderson SS (1990) Seals. Whittet Books, London

Anderson SS, Fedak MA (1987) Grey seal energetics: females invest more in male offspring. J Zool 211:667-679

Avise JC (1994) Molecular markers nâtural history and evolution. Chapman Hall, New York.

Castell JD, Boston LD, Miller RJ, Kenchington T (1995) The potential identification of the geographic origin of lobster eggs from various wild stocks based on fatty acid composition. Can J Fish Aquat Sci 52:1135-1140

Colby RH, Mattacks CA, Pond CM (1993) The gross anatomy cellular structure and fatty acid composition of adipose tissue in captive polar bears. Zoo Biol 12:267-275

Dayton S, Hashimoto S, Dixon W, Pearce ML (1966) Composi- tion of lipid in human serum and adipose tissue during prolonged feeding of a diet high in unsaturated fat. J Lipid Res 7:103-111

Field CJ, Clandinin MT (1984) Modulation of adipose tissue fat composition by diet: a review. Nutr Res 4:743-755

Folch J, Lees M, Sloane-Stanley GH (1957) A simple method for the isolation and purification of total lipids from animal tissues. J Biol Chem 226:497-509

Fredheim B, Holen S, Ugland KI, Grahl-Nielsen O (1995) Fatty acids composition in blubber heart and brain from phocid seals. In: Blix AS, Walloe L, Ultang O (eds) Whales, seals, fish and man. Elsevier Science, Amsterdam, p 153-168

Grahl-Nielsen O, Mjaavatten O (1991) Dietary influence on fatty acid composition of blubber fat of seals as determined by biopsy: a multivariate approach. Mar Biol 110: $59-64$

Grahl-Nielsen O, Mjaavatten O (1995) Marine mammalian fatty acids: a source of information. In: Blix AS, Walloe L, Ultang $O$ (eds) Whales, seals, fish and man. Elsevier Science, Amsterdam, p 141-152

Grahl-Nielson O, Mjaavatten O, Tvedt E (1993) Distinguishing between different populations of harp seal by chemometry of the fatty acid profiles in the jaw bone. Can J Fish Aquat Sci 50:1400-1404

Greenwood PJ (1980) Mating systems, philopatry and dispersal in birds and mammals. Anim Behav 28:1140-1162.

Hammond PS, Prime JH (1990) The diet of British grey seals. Can Bull Fish Aquat Sci 222:243-254

Hammond PS, Hall A.J, Prime JH (1994a) The diet of grey seals around Orkney and other island and mainland sites in north-eastern Scotland. J Appl Ecol 31:340-350

Hammond PS, Hall A.J, Prime JH (1994b) The diet of grey seals in the Inner and Outer Hebrides. J Appl Ecol 31: $737-746$

Henderson RJ, Kalogeropoulos N, Alexis MN (1994) The lipid composition of selected tissues from a Mediterranean monk seal. Lipids 29:577-582

Iverson SJ (1993) Milk secretion in marine mammals in relation to foraging: can milk fatty acids predict diet? Symp Zool Soc Lond 66:263-291

Iverson SJ, Arnould JPY, Boyd IL (1997a) Milk fatty acid signatures indicate both major and minor shifts in the diet of lactating Antarctic seals. Can J Zool 75:188-197

Iverson SJ, Frost KJ, Lowry LF (1997b) Fatty acid signatures reveal fine scale structure of foraging distribution of harbour seals and their prey in Prince William Sound Alaska. Mar Ecol Prog Ser 151:255-271

Kakela R, Hyvarinen $H$ (1996) Site specific fatty acid composition in adipose tissues of several northern aquatic terrestrial mammals. Comp Biochem Physiol 115B:501-514

Kakela R, Hyvarinen H, Vainiotalo P (1993) Fatty acid composition in liver and blubber of the Saimaa ringed seal compared with that of the ringed seal and grey seal from the Baltic. Comp Biochem Physiol 105B:553-565

McConnell BJ, Chambers C, Nicholas KC, Fedak MA (1992) Satellite tracking of grey seals. J Zool 226:271-282

McConnell BJ, Fedak MA, Lovell P, Hammond PS (1999) Movements and foraging areas of grey seals in the North Sea. J Appl Ecol 36:573-590

Plakke T, Berkel J, Beynen AC, Hermus RJJ, Katan MB (1983) Relationship between the fatty acid composition of diet and that of subcutaneous fat in individual human subjects Hum Nutr Appl Nutr 37A:365-372

Pomeroy PP, Fedak MA, Rothery P, Anderson SS (1999) Consequences of maternal size for reproductive expenditure on pupping success of grey seals at North Rona Scotland. Anim Ecol 68:235-253 
Pond CM, Mattacks CA, Gilmour I, Johnston MA, Pillinger CT, Prestrud P (1995) Chemical and carbon isotopic composition of fatty acids in adipose tissue as indicators of dietary history in wild arctic foxes on Svalbard. J Zool 236:611-623

Sargent JR, Parks RJ, Mueller-Harvey I, Henderson RJ (1986) Lipid biomarkers in marine ecology In: Sleigh MA (ed) Microbes in the sea. Ellis Horwood Ltd, Chichester, $p$ $119-138$

Schweigert FJ, Stobo WT, Zucker H (1990) Vitamin E and fatty acids in the grey seal. J Comp Physiol B 159:649-654

Smith RJ, Hobson KA, Koopman HN, Lavigne DM (1996) Distinguishing between populations of fresh-water and saltwater harbour seals using stable-isotope ratios and fatty acids profiles. Can J Fish Aquat Sci 53:272-279

Smith SJ, Iverson SJ, Bowen WD (1997) Fatty acid signatures

Editorial responsibility: Otto Kinne (Editor),

Oldendorf/Luhe, Germany and classification trees: new tools for investigating the foraging ecology of seals. Can J Fish Aquat Sci 54:1377-1386 Storr-Hansen E, Spliid H (1993) Coplanar PCB congener levels and patterns and the identification of separate populations of harbour seals in Denmark. Arch Environ Contam Toxicol 24:44-58

Tjonnenland A, Overvad K, Thorling E, Ewertz M (1993) Adipose tissue fatty acids as biomarkers of dietary exposure in Danish men and women. Am J Clin Nutr 57:629-633

Valero-Garrido D, Lopez-Frias M, Llopis J, Lopez-Jurado M (1990) Influence of dietary fats on the lipid composition of perineal adipose tissue of rats. Ann Nutr Metab $34: 327-332$

West GC, Burns JJ, Modafferi M (1979a) Fatty acid composition of blubber from four species of Bering Sea phocid seals. Can J Zool 57:1289-1295

Submitted: April 12, 1999; Accepted: October 13, 1999

Proofs received from author(s): February 14, 2000 